\title{
Global mindset: a systematic review of the concept
}

Magdalena Kossowska*† https://orcid.org/0000-0003-2292-9307,

Jerzy Rosinski** https://orcid.org/0000-0002-8348-2839

*Jagiellonian University, Krakow, Poland. E-mail: magdalena.kossowska@uj.edu.pl

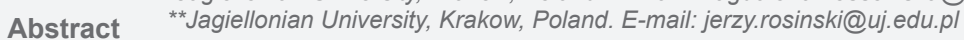

Background. Global mindset (GM) is a relatively new concept slowly gaining the attention of researchers, and it has been heavily influenced by globalisation throughout the years. A better understanding of the term can support companies' growth in international settings and help develop a more effective, skilled workforce. Due to the multiplicity of approaches across the literature, there is a call to systematise available knowledge on GM regarding its antecedents, outcomes, and definitions.

Research aims. The aims of this systematic literature review are to present GM and summarise the available knowledge. This article not only reviews available GM definitions but also addresses its antecedents and outcomes.

Methodology. GM literature was gathered via multiple databases (e.g., ERIC, PsycArticles, PsycINFO, Google Scholar). Two phases of review were incorporated in the process. The first one focused on including peer-reviewed texts and selecting those qualifying for further analyses. The second stage was a content analysis. Two independent judges classified text into specific categories describing the antecedents and outcomes of GM.

Findings. Systematic literature review has shown a multiplicity of GM definitions $(n=18)$, antecedents $(n=179)$, and outcomes $(n=52)$ of GM. As a result, a new GM definition emerged from merging the most common features of the existing ones. This, in turn, reflects a great need to keep on developing our knowledge on the subject and creating clear, applicable structures of the GM concept.

Keywords

Global mindset, systematic review, antecedents, outcomes, definitions

\section{INTRODUCTION}

The aim of this review is to zoom into the global mindset (GM) concept and available literature up to date. Because GM is developing dynamically, it is important to systematise accessible knowledge and set future research trends. This article focuses on reviewing available GM definitions, as well as its antecedents and outcomes.

GM is approached and defined in a number of ways (Bouquet, 2004). For example, Clapp-Smith (2009) outlined it as a general perspective that can be referred to by cognitive complexity, positivity, ability to use judgment to integrate various cultural paradigms, and cultural self-awareness that helps an individual to understand and impact various cultural social interactions and events. Moreover, it is considered vital to understand the concept itself thoroughly, including its antecedents and outcomes, as the GM of managers, entrepreneurs, or employees can help develop more effectiveness in international opportunity identification and lead to a greater number of internationalisation endeavours (He et al., 2020). Andresen and Bergdolt (2017) also outlined GM usefulness within business practises management. Identifying specific skill sets that can lead to GM development can help companies to achieve a competitive advantage in the market and grow quickly within business settings (Niemczyk \& Sus, 2020). Hence, it is important that the concept, as well as its outcomes and antecedents, are well grounded, researched, and understood. This can facilitate further research and have a practical application in skill set development within an international business environment. 


\section{METHOD}

\section{Search strategy}

Databases taken into consideration were EBSCO, Google Scholar, Researchgate.net, Publish or Perish, and Google Search. Keywords used in the search were limited to "global mindset" or "global" AND "mindset" to return the greatest number of results. Only peer-reviewed work was acknowledged for this review. With regards to Publish or Perish software, a different approach was implemented because the number of irrelevant texts resulting from the search was too great. In the "general citations" column and then in the "all of the words" column, the expression "global mindset" was input, and then the search was narrowed to "title words only," which resulted in more relevant search results.

\section{Eligibility criteria}

The literature review was divided into two stages. The first was to search and qualify as many texts as possible that were connected with GM. The next step was to review abstracts and content to eliminate those that did not examine GM in any way. Thus, references that only had GM mentioned in the title but did not refer to the concept in the abstract were removed. One of the criteria considered important in this stage was to eliminate those publications that were not peer-reviewed. The second stage focused on a deeper examination of texts in terms of methodology, researched group, place, GM definition, other variables taken into consideration in the study, whether GM was a dependent variable, and methods used. To access all the required and reliable data, full texts for chosen papers were searched for. After that, the second stage started and the selected texts were further examined.

\section{Independent judging procedure and categories}

Antecedents and outcomes obtained from the literature were grouped into categories by two independent judges (PhD students). They received a file with a list of antecedents and outcomes and their sources, and they were asked to align those to appropriate categories. Descriptions of each category and aligned codes, the abstract text, and the definition of variables coming from the original sources were provided. After that, a third judge grouped variables that were aligned in two different categories by the other two judges to add an additional control factor to the categorisation process.

GM antecedents were categorised into organisational and individual factors. Organisational factors were described as components that include characteristics of a company, describe its global activities, and outline the job complexity and organisational practises within the organisation. It consists of four subcategories. Organisational characteristics describe a company, including its location, size, and industry. An organisational manager's characteristics refer to management structure, a manager's characteristics, and leadership role. Organisational practises refer to human resources practises regarding an organisational strategy. Organisational international activity focuses on a company's global orientation strategy, internationalisation, international branches, employees, and customers.

The category of individual antecedents consists of four subcategories. Demographic factors include variables such as age, gender, education, skills, and family status. International activity describes international action referring to travels, international assignments, international cooperation, and international experience of an individual. Cross-cultural factors focus on variables that include an individual's cultural experiences, cultural intelligence, and knowledge. Psychological factors outline behaviours, attitudes, mental processes, and personality traits of a person, style of behaving, and thinking, and experiences.

Variables that did not fit into any provided categories were classified into the category of other antecedents. Details are shown in Table 1. 
Table 1. Global mindset antecedents' categories

\begin{tabular}{|c|c|c|}
\hline Category & & Description \\
\hline \multirow[t]{4}{*}{ Organisational factors } & $\begin{array}{l}\text { Organisational characteristics } \\
\text { Ananthram et al. (2010), Cole and Konyu-Fogel (2011), Dekker (2013), Felício et al. } \\
\text { (2013), Felício et al. (2012), Kobrin (1994) }\end{array}$ & $\begin{array}{l}\text { Characteristics of a company including } \\
\text { organisation's location, size, and industry }\end{array}$ \\
\hline & $\begin{array}{l}\text { Organisational managers' characteristics } \\
\text { Ananthram et al. (2012), Arora et al. (2004), Dekker (2013), Gupta and } \\
\text { Govindarajan (2002), Levy (2005), March (2013), Massingham (2013), Nielsen } \\
\text { (2014), Nummela et al. (2004), Paul (2000), Ransom (2007), Story et al. (2014) }\end{array}$ & $\begin{array}{l}\text { Factors that refer to management } \\
\text { structure, manager's characteristics, and } \\
\text { leadership role }\end{array}$ \\
\hline & $\begin{array}{l}\text { Organisational practises } \\
\text { Ananthram et al. (2010), Arora et al. (2004), Dekker et al. (2005), Kobrin (1994), } \\
\text { Kwantes and Chung-Yan (2012), Lill (2012), Mikhaylov and Fierro (2015), Nielsen } \\
\text { (2014), Paul (2000), Pucik (2006) }\end{array}$ & $\begin{array}{l}\text { Human resources practise and } \\
\text { organisational strategy }\end{array}$ \\
\hline & $\begin{array}{l}\text { Organisational international activity } \\
\text { Ananthram et al. (2012), Ciszewska-Mlinarič (2015), Cole and Konyu-Fogel (2011), } \\
\text { Dekker (2013); Felício et al. (2013), Felício et al. (2012), Gupta and Govindarajan } \\
\text { (2002), Kwantes and Chung-Yan (2012), Nielsen (2014), Nummela et al. (2004), } \\
\text { Pucik (2006), Story et al. (2014) }\end{array}$ & $\begin{array}{l}\text { Company's global orientation strategy, } \\
\text { internationalisation, international } \\
\text { branches, employees, and customers }\end{array}$ \\
\hline \multirow[t]{4}{*}{ Individual factors } & $\begin{array}{l}\text { Demographic factors } \\
\text { Ananthram et al. (2012), Carvalho (2014), Ciszewska-Mlinarič (2015), Cole and } \\
\text { Konyu-Fogel (2011), Dekker (2013), Felício et al. (2013); Felício et al. (2012); } \\
\text { Javidan and Bowen (2013), Kjar (2007), Matthes (2013), Nielsen (2014), Stokke } \\
\text { (2013), Story et al. (2014) }\end{array}$ & $\begin{array}{l}\text { Components like age, gender, education, } \\
\text { skills, and family status }\end{array}$ \\
\hline & $\begin{array}{l}\text { International activity } \\
\text { Ananthram et al. (2012), Arora et al. (2004), Carvalho (2014), Ciszewska-Mlinarič } \\
\text { (2015), Cole and Konyu-Fogel (2011), Dekker (2013), Dekker et al. (2005), Felício et } \\
\text { al. (2013), Felício et al. (2012), Gupta and Govindarajan (2002); Javidan and Bowen } \\
\text { (2013), Kwantes and Chung-Yan (2012), Lill (2012), Lovvorn and Chen (2011), } \\
\text { March (2013), Matthes (2013), Nielsen (2014), Pucik (2006), Ransom (2007), Story } \\
\text { et al. (2014) }\end{array}$ & $\begin{array}{l}\text { International action referring to travels, } \\
\text { international assignments, international } \\
\text { cooperation, and international experience } \\
\text { of an individual }\end{array}$ \\
\hline & $\begin{array}{l}\text { Cross-cultural factors } \\
\text { Carvalho (2014), Clapp-Smith (2009); Clapp-Smith et al. (2007), Lane et al. (2009), } \\
\text { Lovvorn and Chen (2011), Mikhaylov and Fierro (2015), Nielsen (2014), Ransom } \\
\text { (2007), Stokke (2013), Zander et al. (2012) }\end{array}$ & $\begin{array}{l}\text { Cultural experiences, cultural intelligence, } \\
\text { and knowledge }\end{array}$ \\
\hline & $\begin{array}{l}\text { Psychological factors } \\
\text { Chandwani et al. (2015), Felício et al. (2013), Felício et al. (2012), Lane et al. (2009) }\end{array}$ & $\begin{array}{l}\text { Behaviours, attitudes, mental processes, } \\
\text { personality traits of a person, style of } \\
\text { behaving and thinking, and experiences }\end{array}$ \\
\hline $\begin{array}{l}\text { Other } \\
\text { Dekker et al. (2005) }\end{array}$ & Job experience & \\
\hline
\end{tabular}

Source: Authors' own description, based on research results.

Outcomes were grouped into four categories. Two of them were the same and defined the same way as those used in the categorisation of GM antecedents; that is, organisational international activity and psychological factors. Leadership factors capture a leader's global competencies, skills, behaviours, attributes, and ability to manage others. Performance factors capture global and cross-cultural effectiveness or performance of individuals, teams, managers, companies, or programmes, and ability to adjust to new or changing environments. Once again, variables that did not fit into any provided possibilities were classified into the category of other outcomes. Details are shown in Table 2.

Table 2. Global mindset outcomes categories

\begin{tabular}{ll}
\hline Category & Description \\
\hline $\begin{array}{l}\text { Organisational international activity } \\
\text { Felício et al. (2013), Felício et al. (2012), Felício et al. (2015), Gaffney et al. } \\
\text { (2014), Gonzalez-Loureiro et al. (2015), Levy (2005), Paul (2000) }\end{array}$ & $\begin{array}{l}\text { Company's global orientation strategy, internationalisation, international } \\
\text { branches, employees, and customers }\end{array}$ \\
\hline $\begin{array}{l}\text { Psychological factors } \\
\text { Clapp-Smith (2009), Cruse (2010), Story (2010), Story and Barbuto (2011), } \\
\text { Tran et al. (2015) }\end{array}$ & $\begin{array}{l}\text { Behaviours, attitudes, mental processes, personality traits of a person, style } \\
\text { of behaving and thinking, and experiences }\end{array}$ \\
\hline
\end{tabular}




\begin{tabular}{ll}
\hline Category & Description \\
\hline Leadership & $\begin{array}{l}\text { Leader's global competencies, skills, behaviours, attributes, and ability to } \\
\text { manage others }\end{array}$ \\
$\begin{array}{l}\text { Ananthram and Nankervis (2013), Beechler and Javidan (2007), Bücker and } \\
\text { Johnston (2013), Khilji et al. (2010); Osland et al. (2012), Paul (2000), }\end{array}$ & \\
$\begin{array}{l}\text { Sakchalathorn and Swierczek (2014), Story (2010), Story and Barbuto (2011), } \\
\text { Vakilbashi et al. (2014), Vogelgesang et al. (2014), Zander et al. (2012) }\end{array}$ & \\
\hline $\begin{array}{l}\text { Performance } \\
\text { Addae (2010), Bowen and Inkpen (2009), Chen (2014), Cohen (2010), }\end{array}$ & $\begin{array}{l}\text { Global and cross-cultural effectiveness or performance of individuals, teams, companies, or programmes; ability to adjust to new or changing } \\
\text { Cruse (2010), Dekker (2013), Gagnon (2014), Javidan and Bowen (2013), } \\
\text { Kaczmarek (2009), Lane et al. (2009), Miocevic and Crnjak-Karanovic (2012), }\end{array}$ \\
$\begin{array}{ll}\text { Mohamed (2013), Nummela et al. (2004), Price (2015), Raman et al. (2013), } \\
\text { Ranker et al. (2014), Reis et al. (2012), Stone (2013), Zander et al. (2012) }\end{array}$ \\
\hline $\begin{array}{l}\text { Other } \\
\text { Ng et al. (2011) }\end{array}$
\end{tabular}

Source: Authors' own description, based on research results.

\section{RESULTS}

\section{Search outcomes}

Different databases were searched with the use of a simple search formula: "global mindset" or "global" AND "mindset" search string. The initial output was 290 texts. Two stages of review were applied here. The first stage included removing non-peerreviewed texts and duplicates. Moreover, criteria outlined here were used to include or eliminate publications according to GM availability in the title, abstract, and keywords. After applying those rules, 133 of the 290 texts remained. The second stage was a deeper analysis of the content, so full texts were searched for. A total of 93 full texts were available and included in the second step of this review. The search process and results are described in Figure 1.

Figure 1. Flowchart presenting research process.

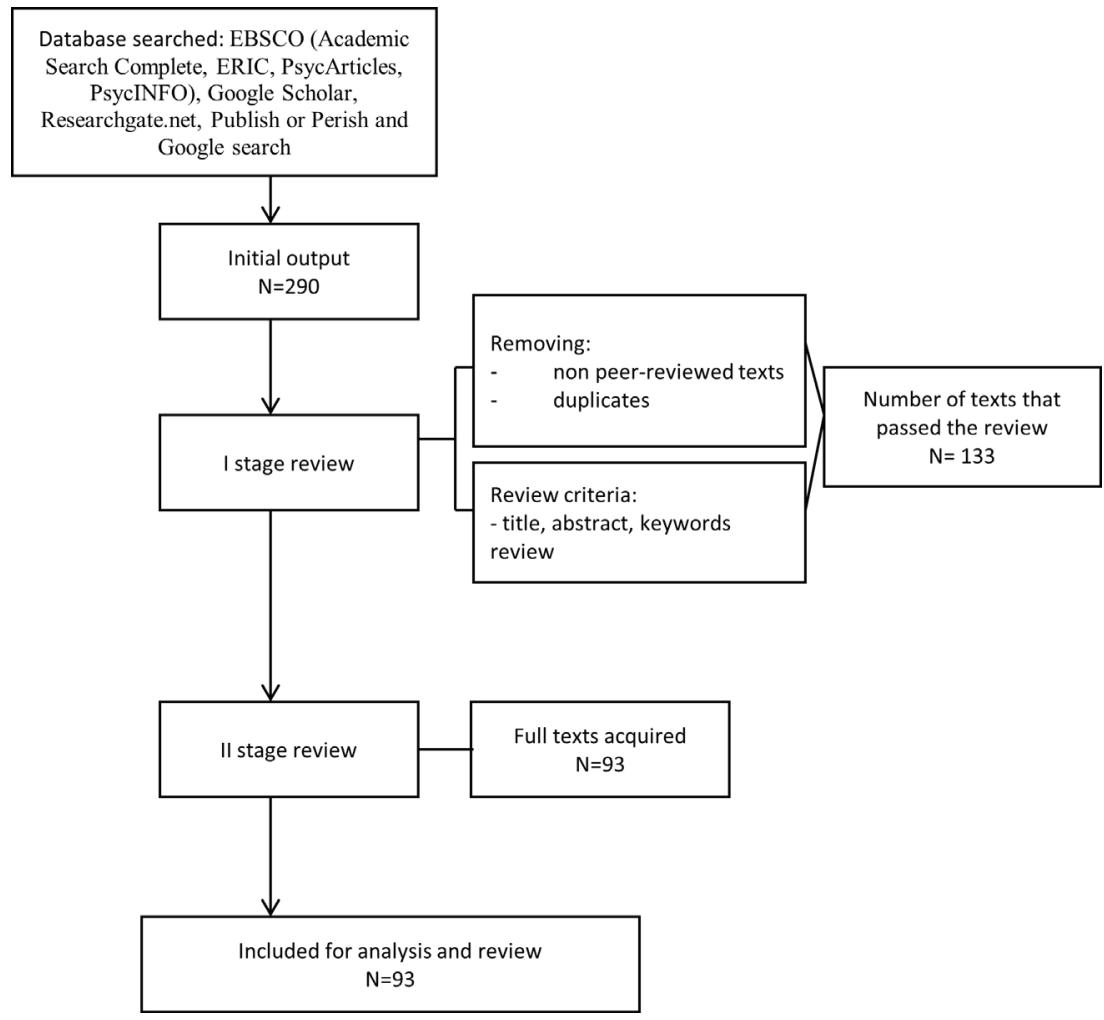

Source: Authors' own description, based on research results. 
Two factors influenced how the findings were grouped: study type and whether GM could be considered as a dependent or independent variable in the study (antecedent or outcome; Tables 1 and 2). Quantitative studies were presented in 36 publications, in which GM was treated as a dependent variable in 15 and as an independent variable in 21 . A smaller number of qualitative studies and complex research designs were found in comparison to quantitative studies. In a total sample of publications, there were nine qualitative studies evenly split between GM treated as a dependent and as an independent variable. There were eight publications with a complex research design in which mostly GM is researched as a dependent variable (seven publications) and only in one publication as an independent one. In a total sample of 93 publications, there were 53 publications presenting empirical studies and 40 presenting literature reviews. Details are shown in Table 3.

Table 3. Types of studies investigating global mindset $(n=93)$

\begin{tabular}{|c|c|c|c|c|}
\hline Study type & & Total no. of publications & Independent variable & Dependent variable \\
\hline \multirow[t]{4}{*}{ Empirical research } & & 53 & 27 & 26 \\
\hline & Quantitative & 36 & 21 & 15 \\
\hline & Qualitative & 9 & 5 & 4 \\
\hline & Complex research & 8 & 1 & 7 \\
\hline Literature review & & 40 & & \\
\hline
\end{tabular}

Source: Authors' own description, based on research results.

Sources differed in terms of types of publications. A considerable number of texts came from peer-reviewed journals $(n=58)$, book chapters $(n=14)$, PhD dissertations $(n=16)$, MA theses $(n=3)$, and MBA theses $(n=2)$. Most of those have an international reach and were written in English (95\%). A sources matrix can be found in the Appendix.

\section{Definitions review}

GM definitions were extracted from available publications, resulting in 18 definitions. GM is approached and described in different ways, but some similarities can be found across the literature and available definitions (Table 4).

Table 4. Global mindset definitions

\begin{tabular}{|c|c|}
\hline Source & Global mindset definition \\
\hline Ananthram et al. (2014) & $\begin{array}{l}\text { It is an ability and willingness to think, act, and transcend goals, boundaries, competencies, and values globally by } \\
\text { managers }\end{array}$ \\
\hline Beechler and Javidan (2007) & $\begin{array}{l}\text { An individual's psychological, knowledge, and cognitive attributes that allow one to influence groups and organisations } \\
\text { that come from various sociocultural systems }\end{array}$ \\
\hline Chatterjee (2005) & $\begin{array}{l}\text { A cognitive orientation that is incorporated in any organisation and shown by its practices and values that in effect show } \\
\text { its ability to transcend immediacy boundaries }\end{array}$ \\
\hline Clapp-Smith (2009) & $\begin{array}{l}\text { General perspective, which is outlined by cognitive complexity, cognitive cultural intelligence, cultural self-awareness, } \\
\text { and positivity; it also includes an individual's ability to integrate multiple cultural paradigms to understand and influence } \\
\text { social interactions and events that are culturally diverse }\end{array}$ \\
\hline Clapp-Smith and Lester (2014) & Dynamic process of mindset switching, appropriate reaction or mindset can be primed to activate for a specific situation \\
\hline Cohen (2010) & $\begin{array}{l}\text { Ability to act in various cultural settings and influence groups, organisations, individuals, and systems that differ } \\
\text { intellectually, socially, and psychologically from one's own knowledge structures }\end{array}$ \\
\hline Javidan and Teagarden (2011) & $\begin{array}{l}\text { An individual's ability to influence individuals, groups, organisations, and systems that are unlike him or her or his or her } \\
\text { own; consists of three facets: } \\
\text { Psychological (passion for diversity, quest for adventure, self-assurance) } \\
\text { Social (intercultural empathy, interpersonal impact, diplomacy) } \\
\text { Intellectual (global business savvy, cognitive complexity, cosmopolitan outlook) }\end{array}$ \\
\hline Levy et al. (2007) & Cognitive capacity to acknowledge and appreciate various cultures \\
\hline $\begin{array}{l}\text { Miocevic and Crnjak-Karanovic } \\
\text { (2012) }\end{array}$ & $\begin{array}{l}\text { A multidisciplinary concept that consists of cultural and cognitive dimensions that influence decision making and } \\
\text { international actions of the company }\end{array}$ \\
\hline Ndum and Onukwugha (2012) & It combines openness to and awareness of cultural diversity and gives an ability to synthesise across it \\
\hline Nielsen (2014) & Managerial metacompetence and organisational capability \\
\hline Nummela et al. (2004) & $\begin{array}{l}\text { Includes attitudinal and behavioural elements; attitudinal aspect outlines the way information is handled, and } \\
\text { behavioural element refers to a manager's openness and awareness to cultural diversity }\end{array}$ \\
\hline
\end{tabular}




\begin{tabular}{|c|c|}
\hline Source & Global mindset definition \\
\hline Pucik (2006) & $\begin{array}{l}\text { Two perspectives: } \\
\text { Psychological attributes and skills needed by managers to be effective within multinational companies } \\
\text { Strategic orientation of the organisation has an effect on managers' behaviours }\end{array}$ \\
\hline Reis et al. (2012) & $\begin{array}{l}\text { Described in two ways: } \\
\text { Cross-cultural—cultural knowledge and sensitivity that gives an ability to work with people from various cultures effectively } \\
\text { Strategic_-global business-savvy attitude, up-to-date knowledge on other markets and economies, and willingness to } \\
\text { create a global network }\end{array}$ \\
\hline Quinonez and Ozyurt (2014) & Capacity to be culturally aware with regards to commonalities across cultures as well as differences that occur \\
\hline Lane et al. (2009) & $\begin{array}{l}\text { Capacity to develop and interpret criteria for personal and business performance that are independent from the } \\
\text { assumptions of a single context; and to implement those criteria appropriately in different contexts }\end{array}$ \\
\hline Gaffney et al. (2014) & Usage of a multidimensional approach, including cognitive complexity, cosmopolitanism, and an external focus \\
\hline Kwantes and Chung-Yan (2012) & $\begin{array}{l}\text { Individual's stock of knowledge, cognitive, and psychological attributes that enable him or her to influence individuals, } \\
\text { groups, and organisations from diverse sociocultural systems }\end{array}$ \\
\hline
\end{tabular}

Source: Authors' own description, based on research results.

\section{Independent judges' interrater reliability}

Interrater reliability $(\mathrm{IRR})$ and Scott's $\mathrm{Pi}(\pi)$ tests were conducted to analyse to which degree provided category ratings were in agreement. For both antecedents and outcomes, two independent judges achieved a high level of agreement. Antecedents IRR reached $70 \%$, and in the case of outcomes, it is $90 \%$. As far as Scott's Pi is concerned, within antecedents there was a high reliability score $(\pi=0.65)$, and outcomes reached a very high reliability $(\pi=0.9)$. Those results show a high level of agreement between the independent judges.

For antecedents, independent judges input 31 variables into organisational factors, 90 for individual factors, and one into the other category. Mismatch was found in 54 cases (those were categorised by a third independent judge). After adding up variables from the third judge, the total number for organisational factors turned out to be 61 and for individual factors it was 119. There was no change within the other category. Details are shown in Table 5.

Table 5. Sum of variables in each category-Global mindset antecedents $(n=179)$

\begin{tabular}{cccc}
\hline Category & Judge 1 + Judge 2 & Judge 3 & Total \\
\hline Organisational characteristics & 5 & 3 & 8 \\
Organisational managers' characteristics & 12 & 3 & 15 \\
Organisational practises & 8 & 8 & 16 \\
Organisational international activity & 11 & 11 & 22 \\
Demographic factors & 21 & 10 & 31 \\
International activity & 41 & 10 & 51 \\
Cross-cultural factors & 12 & 2 & 14 \\
Psychological factors & 16 & 8 & 24 \\
Other & 1 & 0 & 1 \\
\hline
\end{tabular}

Source: Authors' own description, based on research results.

In the case of outcomes, independent judges input 7 into organisational international activity, 6 into psychological factors, 16 within leadership, and 17 in performance. Mismatch was found in the case of five outcomes. A third independent judge categorised those as in the case of antecedents. Thus, the total number for organisational international activity turned out to be 8, psychological factors were 7, leadership was 16, and performance was 20. Details are shown in Table 6.

Table 6. Sum of variables in each category-Global mindset outcomes $(n=52)$

\begin{tabular}{cccc}
\hline Category & Judge $1+$ Judge 2 & Judge 3 & Total \\
\hline Organisational international activity & 7 & 1 & 1
\end{tabular}




\begin{tabular}{cccc}
\hline Category & Judge 1 + Judge 2 & Judge 3 & Total \\
\hline Leadership & 16 & 0 & 16 \\
Performance & 17 & 3 & 20 \\
Other & 0 & 0 & 0 \\
\hline
\end{tabular}

Source: Authors' own description, based on research results.

\section{Antecedents of global mindset}

There are a number of studies focusing on GM antecedents. Independent judges grouped those into two main categoriesorganisational and individual factors-that were then divided into four subcategories each. Table 7 presents the mentioned factors; the first four outline the organisational category and remaining four are from the individual category. There is one that was not included in any of the previously mentioned categories, which is the other categorisation with one variable included.

Table 7. Global mindset antecedents

\begin{tabular}{|c|c|c|}
\hline No. & Category & Antecedents \\
\hline 1 & Organisational characteristics & $\begin{array}{l}\text { Location of employment, product line, total employees of the firm, firm characteristics, technology } \\
\text { intensity; geographic scope of the firm; job hierarchical level }\end{array}$ \\
\hline 2 & Organisational managers' characteristics & $\begin{array}{l}\text { Managers' characteristics, age, level of management, skills and abilities, risk tolerance, global identity, } \\
\text { managerial cognition, geographical scope of managers, composition and attention patterns of top } \\
\text { management, environment in which all managers see themselves as global sources, managers' } \\
\text { international education, international work experience, leadership role, and leadership style }\end{array}$ \\
\hline 3 & Organisational practises & $\begin{array}{l}\text { Human resources practices and strategy of an organisation, training and development, action learning, } \\
\text { formal training, training on the job, career path planning, employee selection, global career paths, } \\
\text { management development programmes, human resources processes, organisational strategy, structural } \\
\text { and strategic characteristics of the firm, entrepreneurial orientation, social capital, encouragement for } \\
\text { managers to network }\end{array}$ \\
\hline 4 & Organisational international strategy & $\begin{array}{l}\text { Percentage of revenue from foreign operations, location of company's headquarters, employee mobility, } \\
\text { firm international experience, company internationalisation, global orientation of the firm, its perspectives } \\
\text { on the global market, market characteristics (globalness of the market, turbulence on the market), } \\
\text { domestics, global or transnational business, percentage of sales and employees, global performance } \\
\text { management systems, firm foreign ownership, boundary-spanning activities, number of countries firm } \\
\text { operates in or conducts business with, complexity of global role, networking, cultivating knowledge } \\
\text { regarding diverse cultures and markets, ability to integrate diverse knowledge bases }\end{array}$ \\
\hline 5 & Demographic factors & $\begin{array}{l}\text { Number of foreign languages spoken, education, work experience, technical and professional expertise, } \\
\text { knowledge, position, nationality, multiple nationalities, age, gender, marital status, number of children, } \\
\text { international marriages, family members of diverse ethnics, early life experiences concerning family and } \\
\text { travel, and family life }\end{array}$ \\
\hline 6 & International activities of an individual & $\begin{array}{l}\text { International assignments, international work experience, international experience, international learning, } \\
\text { education, international travel, international cooperation, valuation of international experience, international } \\
\text { mobility, working in international teams, family, friends, or international background, international activity of } \\
\text { an individual, working with foreign nationals domestically, time studied abroad, learning about host country } \\
\text { by leisure or business, travelling and immersing in the new culture, student exchange programmes, } \\
\text { self-studying about other cultures, the number of countries one has lived in or times per year a person } \\
\text { travelled abroad, global orientation of the entrepreneur, job experience or exposure in other countries, } \\
\text { having a family member of foreign origin, or attitudes towards globalisation (managers' approaches to } \\
\text { global learning opportunities, global human resources, and global learning) }\end{array}$ \\
\hline 7 & Cross-cultural factors & $\begin{array}{l}\text { Cultural intelligence, cultural self-awareness, effective cross-cultural communication, cultural knowledge } \\
\text { creation, cross-cultural competence, diverse cultural background, and motivation to work and lead cross- } \\
\text { culturally, intercultural adaptability, global business knowledge }\end{array}$ \\
\hline 8 & Psychological factors & $\begin{array}{l}\text { Cognitive complexity, positivity, suspending judgment, informal learning, tolerance for ambiguity and } \\
\text { cosmopolitanism, cultivating curiosity about the world, knowledge creation, personality traits, mindfulness, } \\
\text { decision style, attitude in relations, childhood experiences }\end{array}$ \\
\hline 9 & Other & Job experience \\
\hline
\end{tabular}

Source: Authors' own description, based on research results.

Next, we describe various approaches concerning grouping antecedents across the available literature. Some findings from this study are also to be presented.

Ransom (2007) focused on managerial characteristics, intercultural adaptability, and attitudes towards globalisation in conducted research. Attitudes towards globalisation are considered as a mediator here in between intercultural adaptability 
and GM. Results show that there is a partial mediation between the mentioned variables. Intercultural adaptability is found to partially mediate managerial characteristics and attitudes toward globalisation. Significant interrelations are found between GM and attitudes towards globalisation. The main differences in responses turned out to be influenced by managerial level, functions, and world regions.

Story and colleagues (2014) differentiated GM antecedents into categories of personal, psychological, and job-role complexity. As important antecedents, they outlined education, level of management, number of languages spoken, number of international business trips, international assignment experience, complexity of global role, and positive psychological capital (PsyCap). On the other hand, Kjar (2007) outlined early life experiences, family factors and community, and travel as important for GM development. Nationality prominence is also indicated in conducted studies. Matthes (2013) described higher levels of GM in leaders who have dual citizenship. Personal, educational, and professional factors were also shown to mediate the relationship between GM and nationality.

There are other approaches that, for example, group GM antecedents on demographic and organisational levels. The latter referred to such factors as the number of employees in the company, location of headquarters, product lines, and the number of countries a company operates in or does business with. The percentage of employees overseas and revenue received from foreign operations were also taken into consideration. From a demographic perspective, age, gender, position, or such factors as international work experience, number of foreign languages spoken, multicultural background of an individual, or work location are considered significant antecedents of GM. A number of factors were found to increase GM considerably: known foreign languages, countries worked in, employees working overseas, company revenue (Cole \& Konyu-Fogel, 2011). Dekker (2013), on the other hand, distinguished personal and person in job factors. Personal factors refer to number of children, marital status, age, gender, and education (also the one abroad). Person in job factors refers to job characteristics (e.g., geographical scope), international work experience, and how many times an individual travelled per year.

Antecedents of GM also get divided according to level of occurrence, so individual, team or group, and company or organisation. Ciszewska-Mlinarič (2015) distinguished individual and firm-level predictors of GM. The first group refers to prior international experience and language skills, and the second to foreign ownership and international experience of a company. Hruby et al. (2016) undertook an extensive literature research and grouped their findings according to level of appearance. On the individual level, such antecedents are outlined as demographics (e.g., age, gender, and language proficiency; international education), multicultural work experience, multicultural background, international connection or mindset (e.g., expanding knowledge on various cultures), and business-related factors (e.g., operations). On a group level, they specified variables like cognitive capabilities, international experience, cosmopolitan orientation, and cognitive diversity. It is outlined as prominent for GM whether this group is engaged in globalisation issues and international trade practises, has experience of foreign customers and traditions, industry-specific forces, organisational and strategic heritage, and overseas campuses. On an organisational level, Hruby and colleagues (2016) described such antecedents as leadership performance, managers' decision style, top management's capability to do a proper evaluation of gained international experiences, and even their childhood experiences. Moreover, daily language exposure and international experience is considered valid, as well as diversity of available resources and an ability to cultivate knowledge and information about other cultures.

Gupta and Govindarajan (2002), on the other hand, focused on international work experience of managers such as multiyear assignments and creation of an environment in which they would feel like global sources. Having an ability to integrate dispersed cultural knowledge structures as well as willingness to cultivate it is considered an important predictor of GM. Thus, an ability to integrate diverse knowledge bases effectively was considered the most important factor that affects GM development.

Among other antecedents that can be spotted within the available literature, cognitive complexity is described as important for GM (Clapp-Smith, 2009; Clapp-Smith \& Lester, 2014; Clapp-Smith et al., 2007; Hruby et al., 2016; Levy et al., 2007; Pobat, 2013) as are cultural intelligence (Carvalho, 2014; Clapp-Smith, 2009; Clapp-Smith et al., 2007; Hruby et al., 2016; Lovvorn \& Chen, 2011; Zander et al., 2012) and cultural adaptability (Reis et al., 2012). What is more, cultural self-awareness, positivity, and suspending judgment are considered prominent factors (Clapp-Smith, 2009; Hruby et al., 2016). Carvalho (2014) referred to personal characteristics (formal education, language skills, international experience, informal learning) and psychological traits (PsyCap, tolerance for ambiguity, cosmopolitanism, and cultural self-awareness) as predictors of GM. Moreover, Clapp-Smith and colleagues (2007), as well as Beechler and Javidan (2007), identified psychological capital as an important antecedent of GM. Later on, Clapp-Smith and Lester (2014) built upon those findings and added cosmopolitanism to the GM antecedent group. Formal training, as well as training on the job, is considered important for GM development. There are variables that have a positive impact on GM development like foreign country work and living experience, multicultural family, and age (Arora et al., 2004). Moreover, having an international background within work or educational experience was listed as an important antecedent by Nummela and colleagues (2004). They found that such market characteristics as turbulence or globalness are 
prominent factors influencing GM. Lill (2012) outlined that managers on international assingments are the most effective in cultivating GM. Such factors as international travel, work experience, or working in global teams contributed to GM development. The value of international cooperation, assignments, and leadership style was mentioned by March (2013). Leadership style is described by people growth, offering development opportunities, conducting proper induction of new hires, and providing proper training. It is vital to provide fulfilling work opportunities that can keep employees interested in a job (March, 2013). Mikhaylov and Fierro (2015) found out that among antecedents that are vital for GM are social networks, capital, cross-cultural competence, and creating cultural knowledge. Global approach turned out to be an important impact factor for GM. Lane and colleagues (2009) referred to global competencies as antecedents of GM and as the most important ones they have described developing global business knowledge. In their study, they also referred to threshold personality traits (integrity, humility, curiosity, and hardiness or resilience) as vital predictors. On the other hand, Gaffney and colleagues (2014) directed their attention to global integration, international work experience, interactions with foreigners, individuality, and entrepreneurship as important traits for GM development. As far as willingness to cooperate, GM is predicted by team members' willingness to work together. This relationship is mediated by self-efficacy, and it is found that learning orientation is not positively interrelated with GM and cannot be considered as its antecedent (Tran et al., 2015).

Another group of antecedents referred to individual and company characteristics. In the studies published in 2012 and 2013 by Felicio and colleagues, the same set of GM antecedents were outlined: childhood experiences, international experience and its valuation, technical expertise, global orientation and company's global market perspectives, and company's characteristics and global orientation (Felício et al., 2012; Felício et al., 2013). In addition to that, Felício and colleagues (2012) outlined decision style, and later combined decision style and attitude in relations as well as language skills (Felício et al., 2013). Then, in another set of research, Felício et al. (2015) divided antecedents of GM into an individual and corporate categories. The first set builds up from cognition, knowledge, and behaviour when corporate level is referred to as analytical, risk-taking, aggressive, situational, or strategic posture. Moreover, diversity in cultural background, childhood influences like immigrant family or multiple nationalities, knowledge of foreign marriages, international marriage, and motivation to cooperate and lead in a cross-cultural environment were found to be important antecedents of GM (Stokke, 2013).

\section{Outcomes of global mindset}

Outcomes were grouped into five categories. The first four are organisational international activity, psychological factors, leadership, and performance. The final one has only one variable included, and is categorized as other. Outcomes within categories can be found in Table 8.

Table 8. Global mindset outcomes

\begin{tabular}{lll}
\hline No. & Category & Outcome \\
\hline 1 & Organisational international activity & $\begin{array}{l}\text { Internationalisation, global strategic posture of the firm, firm's strategic orientation (global aspiration, capability } \\
\text { seeking, risk tolerance), acculturation }\end{array}$ \\
\hline 2 & Psychological factors & Organisational commitment, confidence, culturally appropriate behaviour, trust in leader \\
\hline 3 & Leadership & $\begin{array}{l}\text { Global leader competencies (ability to be nonjudgmental, inquisitiveness, performance), leader-member } \\
\text { exchange, culturally responsive global leadership, leadership behaviour, global leadership, manager's global } \\
\text { skill sets, how a manager leverages global team diversity, leading a successful global team, leadership } \\
\text { attributes or styles, global leadership development }\end{array}$ \\
\hline 4 & Performance & $\begin{array}{l}\text { Small and medium enterprises' financial and international performance, leadership performance, team and } \\
\text { leadership effectiveness, business performance and effectiveness, global team performance, organisational } \\
\text { performance, company's adaptive capability, trader performance, performance of offshore service providers, } \\
\text { effectiveness of management training programmes in multinational corporations, manager's cross-cultural } \\
\text { communication, internationalisation process measured by company's export performance, international } \\
\text { performance of the firm }\end{array}$ \\
\hline 5 & Other & Global culture capital \\
\hline
\end{tabular}

Source: Authors' own description, based on research results.

Reviewed literature describes performance as organisational (Chen, 2014; Kaczmarek, 2009; Raman et al., 2013; Ranker et al., 2014) and individual (Bowen \& Inkpen, 2009; Price, 2015). Individual performance mostly refers to managers' (Bowen \& Inkpen, 2009) or traders' performance (Price, 2015). In the case of traders, it is found that GM has little direct effect on their performance. GM is considered to rather strengthen network structures that in turn affect an increased performance among traders (Price, 2015). 
Although international cooperation is often considered as an antecedent of $\mathrm{GM}$, as mentioned earlier, cross-cultural communication is described as a GM outcome in the literature. Stone (2013) referred to this outcome as essential in multinational corporations (MNCs) because in a global environment communication styles are influenced by a multiplicity of cultural backgrounds. This presents considerable challenges for managers within MNCs to communicate effectively across structures. Thus, appropriate knowledge of GM can support them in better understanding and functioning in a global environment. A conceptual framework was created with the use of media synchronicity theory and GM. The aim is to support managers in improving their crosscultural communication performance (Stone, 2013).

It should be noted that Hruby and colleagues (2016), in their literature review, grouped GM outcomes on individual, group and organisational levels. On the individual level they listed such GM outcomes as employee commitment, financial indicators of the international performance of firms, leadership, and cross-cultural communication. Team effectiveness or performance is considered important on the group level. The organisational level incorporated such variables as performance, internationalisation, work performance, international behaviour, and enabling the corporate decision-making process. Saputra and Sihombing (2018) also outlined international behavioural control and entrepreneurial intentions as important outcomes of GM.

\section{DISCUSSION AND CONCLUSIONS}

A multiplicity of approaches towards GM can be found across literature (Bouquet, 2004). It is studied equally as a dependent or independent variable within studies. Although research projects are more common, there is a considerable number of literature reviews available. What is more, there are a number of GM definitions available currently $(n=18)$ that have some discrepancies as well as commonalities across the literature. They refer in most cases to cognitive aspects and an ability to influence individuals, groups, and organisations from varied cultural backgrounds. What can also be spotted quite often are such factors as psychological attributes, knowledge structures, or cultural awareness. Thus, after a careful review of available definitions and consideration, GM can be described as a cognitive complexity, cultural awareness, and knowledge structure of an individual that provides an ability to effectively influence other individuals, as well as groups or organisations that come from differentiated cultural backgrounds.

GM antecedents are described as demographic factors such as number of international assignments, business trips, travels, living abroad, having international work experience, or cooperating internationally. Age also gets highlighted as an important GM antecedent, as do cultural intelligence, education, and cognitive complexity. Language proficiency and number of foreign languages known is also an important factor for GM. Moreover, cross-cultural competence, effective cross-cultural communication, leadership position, and personality traits (integrity, humility, curiosity, and hardiness or resilience) are found to have an effect on GM.

With regards to antecedents directly linked with an organisation, a number of factors are described in the literature. Those are number and percentage of employees in the firm, countries a firm operate in or conducts business with, employees overseas, and revenue from foreign operations or company's location. A company's international experience and characteristics, personnel transfer practises, or organisational strategy can also be spotted across the research. Multiple scholars (e.g., Felício et al., 2012; Felício et al., 2013; Gupta \& Govindarajan, 2002; Nummela et al., 2004; Paul, 2000) have outlined the importance of competitiveness on the market, composition of top management and its ability to evaluate international experience, firm perspectives globally, the level of participation in global scanning of the market, discussions about globalisation, or its level of engagement in globalisation issues and international trade practise.

The most commonly studied outcomes of GM are leadership, internationalisation, and organisational commitment. Performance is studied from an individual perspective (mostly that of managers) as well as that of team effectiveness. Other factors can also be spotted within the literature, and although their number is scarce, they add up to available knowledge on GM outcomes. Those include trust and leader-member exchange, confidence, cross-cultural communication, firm strategic orientation, and culturally appropriate behaviour.

Moreover, the GM concept is considered to increase effectiveness in making business decisions in a global context. It goes beyond such concepts as cultural intelligence, which can primarily enable successful coping in cross-cultural surroundings. GM can bring the possibility of increased effectiveness in business practises management and their utility evaluation for the company internationally (Andresen \& Bergdolt, 2017). In another review, GM is discussed in the light of the resource-based view approach and global companies. A specific set of skills (e.g., process-related competencies, competencies resulting from knowledge) within global organisations can lead to GM. This brings empowerment for the business environment and considerable competitive advantage (Niemczyk \& Sus, 2020) 
This literature review of the GM construct shows a great need to continue developing and building on existing knowledge, keeping in mind not only antecedents but also outcomes. The multiplicity of methods used to research GM and the definitions available evidence a great need to create a unified, clearer approach. This has also been outlined by the latest review on GM by Hruby et al. (2018), calling out the need to increase research on variables' operationalisation. In their review, they focused on individual dimensions of GM within managers; however, they outlined that it is important to adopt complex models in the research with a focus on global companies that have greater engagement in international assignments.

\section{REFERENCES}

Addae, H. (2010). The impact of emerging market context and global mindset on training programmes in multinational companies [Unpublished master's thesis]. University of Pretoria.

Ananthram, S., Grainger, R., \& Tominaga, H. (2014). Constituents of a global mindset: An empirical study with Japanese managers. Japan Studies Review, 18, 89-114.

Ananthram, S., \& Nankervis, A. (2013). Global managerial skill sets, management development, and the role of HR: An exploratory qualitative study of North American and Indian managers. Contemporary Management Research, 9(3), 299-322. https://doi.org/10.7903/cmr.9731

Ananthram, S., Pearson, C., \& Chatterjee, S. (2010). Do organisational reform measures impact on global mindset intensity of managers? Empirical evidence from Indian and Chinese service industry managers. Journal of Chinese Economic and Foreign Trade Studies, 3(2), 146-168.

Ananthram, S., Pick, D., \& Issa, T. (2012). Antecedents of a global mindset: A mixed method analysis of Indian, Chinese and Japanese managers. Contemporary Management Research, 8(4), 305-329.

Andresen, M., \& Bergdolt, F. (2017). A systematic literature review on the definitions of global mindset and cultural intelligence-Merging two different research streams. The International Journal of Human Resource Management, 28(1), 170-195. https://doi.org/10.1080/0958519 2.2016.1243568Arora, A., Jaju, A., Kefalas, A. G., \& Perenich, T. (2004). An exploratory analysis of global managerial mindsets: A case of U.S. textile and apparel industry. Journal of International Management, 10(3), 393-411.

Beechler, S., \& Javidan, M. (2007). Leading with a global mindset. In M. Javidan, R. Steers, \& M. Hitt (Eds.), Advances in international management: The global mindset (Vol. 19, pp. 131-169). Emerald Group. http://doi.org/10.1016/S1571-5027(07)19006-9

Bouquet, C. (2004). Building global mindsets. Palgrave Macmillan. http://www.palgraveconnect.com/doifinder/10.1057/9780230522558

Bowen, D. E., \& Inkpen, A. C. (2009). Exploring the role of "global mindset" in leading change in international contexts. Journal of Applied Behavioral Science, 45(2), 239-260. https://doi.org/10.1177/0021886309334149

Bücker, J., \& Poutsma, E. (2010). Global management competencies: A theoretical foundation. Journal of Managerial Psychology, 25(8), 829-844. https://doi.org/10.1108/02683941011089116

Carvalho, A. (2014). An empirical study on the global mindset antecedents [Unpublished master's thesis]. Nova University Lisbon.

Chandwani, R., Agrawal, N., \& Kedia, B. (2015). Mindfulness: Nurturing global mindset and global leadership. Thunderbird International Business Review, 58 (6), 617-625. https://doi.org/10.1002/tie.21760

Chatterjee, S. (2005). Weaving the threads of a global mindset in work organizations managerial roles and responsibilities. Journal of Human Values, 11(1), 37-47. https://doi.org/10.1177/097168580401100104

Chen, S.-J. (2014). The effects of social networks and a global mindset on Taiwanese manufacturing SMEs' ability to form alliances to increase international and financial performance. ProQuest Information \& Learning.

Ciszewska-Mlinarič, M. (2015). Global mindset and internationalization of Polish SMEs: Antecedents and outcomes. Problemy Zarzadzania, 13(1), 93-111. https://doi.org/10.7172/1644-9584.51.7

Clapp-Smith, R. (2009). Global mindset development during cultural transitions [Unpublished doctoral dissertation]. University of Lincoln.

Clapp-Smith, R., \& Lester, G. (2014). Defining the "mindset" in global mindset: Modeling the dualities of global leadership. In J. S. Osland, M. Li, \& Y. Wang (Eds.), Advances in global leadership (Vol. 8, pp. 205-228). Emerald Group. http://www.emeraldinsight.com/doi/abs/10.1108/ S1535-120320140000008017

Clapp-Smith, R., Luthans, F., \& Avolio, B. J. (2007). The role of psychological capital in global mindset development. In M. Javidan, R. Steers, \& M. Hitt (Eds.), Advances in international management (Vol. 19, pp. 105-139). Emerald Group. https://doi.org/10.1016/S15715027(07)19005-7

Cohen, S. (2010). Effective global leadership requires a global mindset. Industrial and Commercial Training, 42(1), 3-10. https://doi. org/10.1108/00197851011013652

Cole, M. L., \& Konyu-Fogel, G. (2011). Analyzing the effects of demographic and organizational factors on global mindset of business leaders: An empirical multi-industry study from five continents. The Journal of International Business Research and Practice, 5, 4-35. 
Cruse, S. (2010). In search of the global mindset: Predicting when a global context will affect leader confidence and judgment [Unpublished doctoral dissertation]. Hofstra University.

Dekker, W. (2013). Global mindset and leadership effectiveness. Palgrave Macmillan.

Dekker, W., Jansen, P., \& Vinkenburg, C. (2005). Dimensions of an individual global mindset. Research Memoranda VU Periodicals, 14, 1-29.

Felício, J., Caldeirinha, V., \& Rodrigues, R. (2012). Global mindset and the internationalization of small firms: The importance of the characteristics of entrepreneurs. International Entrepreneurship and Management Journal, 8(4), 467-485. https://doi.org/doi:10.1007/s11365-012-0232-5

Felício, J. A., Caldeirinha, V. R., Rodrigues, R., \& Kyvik, O. (2013). Cross-cultural analysis of the global mindset and the internationalization behavior of small firms. International Entrepreneurship and Management Journal, 9(4), 641-654. https://doi.org/10.1007/s11365-013-02681

Felício, J., Duarte, M., \& Rodrigues, R. (2015). Global mindset and SME internationalization: A fuzzy-set QCA approach. Journal of Business Research, 69(4), 1372-1378. http://dx.doi.org/10.1016/j.jbusres.2015.10.110

Gaffney, N., Cooper, D., Kedia, B., \& Clampit, J. (2014). Institutional transitions, global mindset, and EMNE internationalization. European Management Journal, 32(3), 383-391. https://doi.org/10.1016/j.emj.2013.08.001

Gagnon, J.-P. (2014). Global team effectiveness: Evaluating the role of transformational leadership and global mindset in geographically dispersed business teams [Unpublished doctoral dissertation]. University of Pennsylvania.

Gonzalez-Loureiro, M., Kiessling, T., \& Dabic, M. (2015). Acculturation and overseas assignments: A review and research agenda. International Journal of Intercultural Relations, 49, 239-250. https://doi.org/10.1016/j.jintrel.2015.05.003

Gupta, A., \& Govindarajan, V. (2002). Cultivating a global mindset. The Academy of Management Executive, 16(1), 116-126. https://doi. org/10.5465/AME.2002.6640211

He, C., Baranchenko, Y., Lin, Z., Szarucki, M., \& Yukhanaev, A. (2020). From global mindset to international opportunities: The internationalization of Chinese SMEs. Journal of Business Economics and Management, 21(4), 967-986. https://doi.org/10.3846/jbem.2020.12673

Hruby, J., de Melo, R. J., Samunderu, E., \& Hartel, J. (2018). Unpacking the complexities of global mindset: A multi-lens analysis. In J. S. Osland, M. E. Mendenhall, \& L. Ming (Eds.), Advances in global leadership (Vol. 11, pp. 97-143). Emerald Publishing. https://doi. org/10.1108/S1535-120320180000011004

Hruby, J., Watkins-Mathys, L., \& Hanke, T. (2016). Antecedents and Outcomes of a Global Mindset: A Thematic Analysis of Research from 1994 to 2013 and Future Research Agenda. In J. S. Osland, M. Li, \& M. E. Mendenhall (Eds.), Advances in Global Leadership (Vol. 9 , pp. 213-280). Emerald Group Publishing Limited. http://dx.doi.org/10.1108/S1535-120320160000009008

Javidan, M., \& Bowen, D. (2013). The "global mindset" of managers: What it is, why it matters, and how to develop it. Organizational Dynamics, 42(2), 145-155. https://doi.org/10.1016/j.orgdyn.2013.03.008

Javidan, M., \& Teagarden, M. (2011). Conceptualizing and measuring global mindset. In W. H. Mobley, Y. Wang, \& M. Li (Eds.), Advances in global leadership (Vol. 6, pp. 13-39). Emerald Group.

Johnston, A. M. (2013). Narratives as navigation tools in support of executive global leadership development [Unpublished doctoral dissertation]. Fielding Graduate University.

Kaczmarek, S. (2009). Nationality, international experience diversity and firm internationalisation: The implications for performance [Unpublished doctoral dissertation]. University of St. Gallen.

Khilji, S., Davis, E., \& Cseh, M. (2010). Building competitive advantage in a global environment: Leadership and the mindset. In T. Devinney, T. Pedersen, \& L. Tihanyi (Eds.), Advances in international management (Vol. 23, pp. 353-373). Emerald Group.

Kjar, R. C. (2007). Global mindset: Characteristics and contributing factors [Unpublished doctoral dissertation]. Benedictine University.

Kobrin, S. J. (1994). Is there a relationship between a geocentric mindset and multinational strategy? Journal of International Business Studies, 3, 493-511.

Kwantes, T., \& Chung-Yan, A. (2012). Developing a global mindset for leaders: The case of the Canadian context. In W. H. Mobley, Y. Wang, \& M. Li (Eds.), Advances in global leadership (Vol. 7, pp. 295-320). Emerald Group.

Lane, H. W., Maznevski, M., Deetz, J., \& DiStefano, J. (2009). International management behavior: Leading with a global mindset (6th ed.). Wiley.

Levy, O. (2005). The influence of top management team attention patterns on global strategic posture of firms. Journal of Organizational Behavior, 26(7), 797-819.

Levy, O., Beechler, S., Taylor, S., \& Boyacigiller, N. A. (2007). What we talk about when we talk about "global mindset": Managerial cognition in multinational corporations. Journal of International Business Studies, 38(2), 231-258.

Lill, T. V. (2012). The most effective methodologies to cultivate a global mindset [Unpublished master's thesis]. University of Pretoria.

Lovvorn, A., \& Chen, J. (2011). Developing a global mindset: The relationship between an international assignment and cultural intelligence. International Journal of Business and Social Science, 2(9), 275-283. 
March, R. (2013). Global mindset, global success at Tata Consultancy Services. South Asian Journal of Global Business Research, 2(1), 27-32.

Massingham, P. (2013). Cognitive complexity in global mindsets. International Journal of Management, 30(1), $232-248$.

Matthes, H. (2013). Antecedents of global mindset: A comparison among German, U.S., and dual citizen leaders [Unpublished doctoral dissertation]. Lawrence Technological University.

Mikhaylov, N., \& Fierro, I. (2015). Social capital and global mindset. Journal of International Education in Business, 8(1), 59-75. https://doi. org/10.1108/JIEB-09-2014-0018

Miocevic, D., \& Crnjak-Karanovic, B. (2012). Global mindset-A cognitive driver of small and medium-sized enterprise internationalization: The case of Croatian exporters. EuroMed Journal of Business, 7(2), 142-160.

Mohamed, N. R. (2013). Examining the relationship between organizational culture, global mindset, and team effectiveness in American global corporations [Unpublished doctoral dissertation]. Northcentral University.

Nationality, international experience diversity and firm internationalisation: The implications for performance. (2009). [Unpublished doctoral dissertation]. University of St. Gallen.

Ndum, V., \& Onukwugha, C. (2012). Global mindset and sustainable development in Africa-A synergy. Mediterranean Journal of Social Sciences, 3(13), 29-37.

Ng, K. Y., Tan, M. L., \& Ang, S. (2011). Global culture capital and cosmopolitan human capital: The effects of global mindset and organizational routines on cultural intelligence and international experience. In I. A. Burton \& J. C. Spender (Eds.), The Oxford handbook of human capital (pp. 96-119). Oxford University Press.

Nielsen, R. (2014). Mindset as managerial meta-competence and organizational capability: Boundary-crossing leadership cooperation in the MNC: The case of "group mindset" [Unpublished doctoral dissertation]. Copenhagen Business School.

Niemczyk, J., \& Sus, A. (2020). The concept of global competencies of corporations in the context of a global mindset. European Research Studies Journal, XXIII(Special Issue 2), 30-39. https://doi.org/10.35808/ersj/1806

Nummela, N., Saarenketo, S., \& Puumalainen, K. (2004). A global mindset—A prerequisite for successful internationalization? Canadian Journal of Administrative Sciences, 21(1), 61-64.

Osland, J. S., Bird, A., \& Mendenhall, M. (2012). Developing global mindset and global leadership capabilities. In G. K. Stahl, I. Björkman, \& S. S. Morris (Eds.), Handbook of research in international human resource management ( $2^{\text {nd }}$ ed., pp. 220-252). Edward Elgar.

Paul, H. (2000). Creating a global mindset. Thunderbird International Business Review, 42(2), 187-200. https://doi.org/10.1002/15206874(200003/04)42:2<187::AID-TIE4>3.0.CO;2-7

Pobat, M. (2013). It is all in the mind of the manager_Using cognitive complexity to explore the global_A comparative case study [Unpublished doctoral dissertation]. George Washington University.

Price, R. W. (2015). Global mindset, networks and trader performance: A study of the global grain and oilseed sector [Unpublished master's thesis]. Victoria University of Wellington.

Pucik, V. (2006). Reframing global mindset: From thinking to acting. In W. H. Mobley \& E. Weldon (Eds.), Advances in global leadership (Vol. 4 , pp. 83-100). Emerald Group.

Quinonez, M., \& Ozyurt, S. (2014). Global leadership mindset and workforce engagement in nonprofit organizations. Journal of Leadership and Management, 1(1). http://leadership.net.pl/index.php/JLM/article/view/17

Raman, R., Chadee, D., Roxas, B., \& Michailova, S. (2013). Effects of partnership quality, talent management, and global mindset on performance of offshore IT service providers in India. Journal of International Management, 19, 333-346.

Ranker, G., Huang, D., \& McLeod, M. (2014). Navigating U.S. and Chinese business cultures using global mindset leadership. Leader to Leader, 75, 23-30. https://doi.org/10.1002/ltl.20162

Ransom, L. K. (2007). Shifting strategic paradigms: Assessing the determinants of global mindset in a United States based diversified transnational corporation [Unpublished doctoral dissertation]. University of Minnesota.

Reis, G., Fleury, M., \& Fleury, A. (2012). Impacts of global mindset and psychic distance on the performance of Brazilian subsidiaries. In M. A. Marinov \& S. T. Marinova (Eds.), Impacts of emerging economies and firms on international business (pp. 126-144). Palgrave Macmillan.

Sakchalathorn, S., \& Swierczek, F. W. (2014). Exploring the globality of executives: Universal or adaptive. Journal of Research in Business and Management, 2(9), 40-52.

Saputra, T. F., \& Sihombing, S. (2018). Application of the theory of planned behavior for predicting the intention of international entrepreneurship: Global mindset and cultural intelligence as moderation variables. Asia-Pacific Management and Business Application, 7(2), 59-80.

Stokke, P. (2013). Adult third culture kids: Potential global leaders with global mindset [Unpublished doctoral dissertation]. Drexel University.

Stone, K. Y. (2013). Integrating media synchronicity theory and global mindset to improve cross-cultural communication performance [Unpublished doctoral dissertation]. University of Maryland. 
Story, J. S. (2010). Testing the impact of global mindset on positive outcomes: A multi-level analysis [Unpublished doctoral dissertation]. University of Nebraska.

Story, J. S., \& Barbuto, J. E. (2011). Global mindset: A construct clarification and framework. Journal of Leadership \& Organizational Studies, 18(3), 377-384. https://doi.org/10.1177/1548051811404421

Story, J. S. P., Barbuto, J. E., Jr., Luthans, F., \& Bovaird, J. A. (2014). Meeting the challenges of effective international HRM: Analysis of the antecedents of global mindset. Human Resource Management, 53(1), 131-155. https://doi.org/10.1002/hrm.21568

Tran, T., Oh, C., \& Choi, S. (2015). Effects of learning orientation and global mindset on virtual team members' willingness to cooperate in: The mediating role of self-efficacy. Journal of Management \& Organization, 22(3), 1-17. https://doi.org/10.1017/jmo.2015.37

Vakilbashi, A., Wan Ismail, W. K., \& Mokhber, M. (2014). The interactions between culture, global mindset, and leadership in global context. Journal of Social Economics Research, 1(8), 191-197.

Vogelgesang, G., Clapp-Smith, R., \& Osland, J. (2014). The relationship between positive psychological capital and global mindset in the context of global leadership. Journal of Leadership \& Organizational Studies, 21(2), 165-178. https://doi.org/10.1177/1548051813515515

Zander, L., Mockaitis, A. I., \& Butler, C. L. (2012). Leading global teams. Journal of World Business, 47(4), 592-603. https://doi.org/10.1016/j. jwb.2012.01.012 


\section{APPENDIX}

Sources matrix

Publications

No. of publications

Academy of Management Executive

Advances in Global Leadership

Asia-Pacific Management and Business Application

Canadian Journal of Administrative Sciences

Contemporary Management Research

EuroMed Journal of Business

European Management Journal

FEWEB Research Memoranda, VU Periodicals

Human Resource Management

International Business and Management

Industrial and Commercial Training

International Business Review

International Entrepreneurship and Management Journal

International Journal of Intercultural Relations

International Journal of Management

Journal of Business and Social Science

Journal of Business Research

Journal of Human Values

Journal of International Education in Business

Journal of Leadership Studies

Journal of Management Development 
Publications

Leader to Leader

Management International Review

Management Decision

Mediterranean Journal of Social Sciences

Organizational Dynamics

Problemy Zarządzania

Revista de Administração da UFSM

Revista Alcance

South Asian Journal of Global Business Research

The Journal of International Business Research and Practice

Thunderbird International Business Review

Japan Studies Review

PhD dissertations

MBA theses

MA theses

Book chapters

No. of publications

1

1

16

2

3

14 